\title{
META ANALYSIS: KANGAROO MOTHER CARE TO ELEVATE INFANT WEIGHT IN PREMATURE INFANTS
}

\author{
Ines Ratni Pravitasari'), Vitri Widyaningsih²), Bhisma Murti1) \\ ${ }^{1)}$ Masters Program in Public Health, Universitas Sebelas Maret \\ 2)Faculty of Medicine, Universitas Sebelas Maret
}

\begin{abstract}
Background: Premature birth is most often challenge with many health issues such as low birth weight. Kangaroo position is the practice of skin-to-skin contact between an infant and parents and was found to be an effective intervention for improving weight gain in premature infant. This study aimed to investigate the effectiveness of kangaroo mother care to elevate infant weight in premature infants.

Subjects and Method: This was a meta-analysis and systematic review. This study collected published articles from PubMed, Science Direct, and Google Scholar databases. The inclusion criteria were full text, in English language, and using randomized control trial study design. The study population was premature infants. The intervention was kangaroo mother care. The comparison was conventional care. The outcome was infant weight. The selected articles were analyzed using RevMan 5.3.

Results: 9 articles were met the study criteria. This study had high heterogeneity between groups $\left(\mathrm{I}_{2}=89 \% ; \mathrm{p}<0.001\right)$. Kangaroo mother care was higher elevated infant weight than conventional method (Standardized Mean Difference= $0.60 ; 95 \% \mathrm{CI}=0.17$ to $1.03 ; \mathrm{p}=0.006$ ).

Conclusion: Kangaroo mother care is effective to elevate infant weight in premature infants.
\end{abstract}

Keywords: Kangaroo mother care, infant weight, preterm infant

\section{Correspondence:}

Ines Ratni Pravitasari. Masters Program in Public Health, Universitas Sebelas Maret. Jl. Ir. Sutami 36A, Surakarta 57126, Central Java. Email: inesratnip@gmail.com. Mobile: +6285649507909 . 